\title{
ПОНЯТТЯ ПРОПАГАНДИ ВІЙНИ: ІСТОРИКО-ПРАВОВИЙ АСПЕКТ
}

Коруч У. 3.

У науковій статmі досліджено сутність пропаганди війни в історично-правовому контексті. Розглянуто питання визначення поняття пропаганди, їі розуміння, значення в юридичних словниках, застосування та закріплення в сучасних документах.

Автор звертає увагу на те, що пропаганда війни має багатовікову історію та сам термін вживався неоднозначно, як і з позитивного на ранніх етапах, так і негативного сприйняття. Відзначено, що в міжнародному праві немає узгодженого визначення терміну пропаганди, зокрема пропаганда війни чи мови ненависті (мова ворожнечі). Досліджено термін пропаганда в етимологічному, лінгвістичному, правовому аспекті.

Підкреслюється, що зацікавленість у питанні пропаганди непостійна в часі, превалює акцент на воєнній пропаганді, особливо ворожій. Проведений аналіз дає підстави зробити висновки про те, що воєнний контекст вживання слова пропаганда значно вплинув на значення самого слова, ставлення до пропаганди, а також методи, що застосовуються при їі вивченні.

Ключові слова: пропаганда, пропаганда війни, міжнародне право, злочин, війна.

В научной статье исследована сущность пропаганды войны в историко-правовом контексте. Рассмотрены вопросы определения понятия пропаганды, ее понимание, значение в юридических словарях, применение и закрепленные в современных документах.

Автор обращает внимание на то, что пропаганда войны имеет многовековую историю и сам термин употреблялся неоднозначно, как и с положительной на ранних этапах, так и с негативной точки зрения. Отмечено, что в международном праве нет согласованного определения срока пропаганды, в частности пропаганда войны или языка ненависти (язык вражды). Исследовано срок пропаганда в этимологическом, лингвистическом, правовом аспекте.

Подчеркивается, что заинтересованность в вопросе пропаганды непостоянна во времени, превалирует акцент на военной пропаганде, особенно вражеской. Проведенный анализ дает основания сделать выводы, что военный контекст употребления слова пропаганда значительно повлиял на значение самого слова, отношение к пропаганде, а также методы, применяемые при ее изучении.

Ключевые слова: пропаганда, пропаганда войны, международное право, преступление, война.

The scientific article deals with the essence of war propaganda in the historical and legal context. The question of definition of the concept of propaganda, its understanding, meaning in legal dictionaries, application and already consolidation in modern documents are considered.

The author draws attention to the fact that propaganda of the war has a centuries-old history and the term itself has been used ambiguously, both from the positive in the early stages and the negative perception. It is noted that there is no harmonized definition of the term propaganda in international

Коруц У. 3., 2019 law, including propaganda of war or hate speech. The term "propaganda" has been researched in the etymological, linguistic, legal aspect.

It is emphasized that the interest in propaganda is unstable in time, and the emphasis on military propaganda, especially hostile, prevails. The conducted analysis gives grounds to conclude that the military context of the use of the word propaganda significantly influenced the meaning of the word itself, attitude to propaganda, as well as the methods used in its study.

The authors note that the Rome Statute of the International Criminal Court does not contain provisions such a crime composition as propaganda of war, and considers that "direct and public incitement to aggression" or war propaganda should be included in the Rome Statute of the ICC as an independent (separate) international crime.

It is noted that the UN General Assembly resolution indirectly interprets the term "propaganda of war" in the resolution "Measures to be taken against propaganda and incendiaries of the new war", noting that it "condemns any kind of propaganda of war being waged, intended or capable of creating or to heighten the threat of peace, the breach of peace or the act of aggression". Thus, the UN has determined that war propaganda can take many forms and is aimed at creating or exacerbating the threat of peace, the breach of peace, or acts of aggression.

Author concludes that propaganda of war is an instrument of directional pressure of one state on the society, population, social groups of another state, which does not cause direct destruction of objects of the material world, but leads to deformation of public consciousness, threats to social psychology, national unity. That is, propaganda of war has clearly pronounced negative consequences for society, invisible at first glance due to the fact that the manifestations of deformation of the mental state of man are manifested only later.

Key words: propaganda, war propaganda, international law, crime, war.

Постановка проблеми. Пропаганда війни має багатовікову історію. У той же час на ранніх етапах розвитку цього суспільно небезпечного явища вона виражалися та проявлялась у різних формах та мала епізодичний характер. Пропаганда війни як злочин повинна розглядатися не лише в суто кримінально-правовому розрізі, як діяльність апріорі протиправна, але й у розрізі національної інформаційної безпеки. Адже пропаганда війни, як сукупність негативних за своїм соціальним забарвленням дій, спрямовується на інформаційне середовище, деформуючи інформацію щодо гострих соціальних питань. У свою чергу це призводить до деформації суспільної свідомості, формуванню стійкої точки зору в певних соціальних груп стосовно певних проявів соціальної несправедливості, які можуть бути вирішені виключно за рахунок військових дій. Тобто пропаганда як злочин $\epsilon$ надзвичайно складною для точної кваліфікації форм протиправної поведінки, оскільки невизначеність та інколи прихована природа ії негативних наслідків суттєво зменшують розмір шкоди або 
інший негативний ефект, який може бути покладений в основу встановлення відповідного виду та міри кримінальної відповідальності.

Аналіз останніх досліджень і публікацій. Міжнародно-правові аспекти пропаганди війни виступили предметом наукового аналізу вітчизняних та зарубіжних дослідників, таких як Л.В. Губерський, Д.В. Скринька, Й. Дінштайн, М. Керні, Д. Макголдрік, Т. Макгонагл, В.В. Маклаков, Г. Майкл, Т. Мендель. Разом із цим потребують подальшого з'ясування питання щодо змісту та структури феномену пропаганди війни, а також репрезентації вказаного поняття в міжнародному праві та національному законодавстві.

Метою статті $\epsilon$ дослідити поняття пропаганди війни в історико-правовому аспекті на основі норм міжнародного права та історичних фактів.

Виклад основного матеріалу. Перш ніж аналізувати поняття «пропаганда війни», спробуємо з'ясувати зміст терміну «пропаганда». В етимологічному значенні пропаганда $\epsilon$ особливим видом соціальної діяльності, метою якої $\epsilon$ поширення знань, інформації для формування певних поглядів, уявлень та емоційного стану. Сьогодні вона $\epsilon$ важливою частиною інформації системи суспільства [1, ст.27].

Історія слова «пропаганда» $\epsilon$ досить показовою у значенні слова, які можна розглядати як наслідок ідеологічних і культурних змін. Майже до XVI ст. слово пропаганда являлось латинським терміном, який використовувався тільки в біології у зв'язку з розмноженням тварин та рослин. Папа Григорій XIII (1572-1585) уповноважив трьох кардиналів «de propaganda fide» поширювати католицьку віру в нехристиянських землях. У 1622 році Григорій XV створив святе братство de propaganda fide. У 1627 році Урбан VIII заснував collegium de propaganda з метою навчання місіонерської діяльності. Латинське слово propaganda у перекладі Вільяма Флечера означає «те, що повинне розповсюджуватись» і вносить деякі зміни в семантику слова «віра» [2].

Вагоме дослідження американського автора Феллоуз Ерні зосереджене на історичних аспектах, зокрема, автор відзначає, що в англійській мові слово пропаганда вперше появилось в 1718 році, відповідно до Оксфордського словника, $\epsilon$ посилання на The Congregation of the Propaganda. Тоді воно було застосоване в релігійному контексті. Дане поняття незмінно носило релігійне забарвлення впродовж XVIII-XIX століть. А вже в XIX ст. зафіксовано вживання слова в політичному та воєнному аспекті. Зокрема, в 1800 році в газеті Philadelphia Aurora була опублікована наступна замітка: «Нам удалось отримати корисну інформацію стосовно Ілюмінатів штату Коннектикут та Массачусетс, а нещодавно стосовно подібної пропагандистської діяльності в штаті Делавер». У 1824 році Даніел Ребстер, виступаючи в Конгресі із промовою щодо революції у Греції застосував вислів: «Багато хто може вважати рішення донкіхотським, від якого віє духом походів чи пропагандистським духом». А в 1852 році Міллард Філмор відзначив: «<...>ця нація не може стати пропагандистом свободи, допоки не підніметься проти Обєднаних сил Європи» [2].

У контексті лінгвістики чимало дослідників відзначили, що вживання слова пропаганда в політичному контексті вперше появилось в Америці. Проте точне місце походження політичного значення слова невідоме.
У 1943 році у словнику з'явилось визначення, в якому відзначалось нерелігійне значення слова: «Першочергово означаючи розповсюдження віри в сучасній політичній мові, слово пропаганда $\epsilon$ терміном, який означає докір таємним спільнотам за розповсюдження поглядів та принципів, які викликають жах і відразу в більшості правління». У такий спосіб до середини XIX століття в більшості частинах світу за словом закріпились негативні конотації.

Варто зазначити, що слово пропаганда (включає похідні від нього форми пропагандист, пропагувати У. К.) не було в широкому вжитку в XVIII і XIX століттях. Сильним поштовхом до його застосування стала Перша світова війна (1914-1918 рр.). Проте Уілл Ірвін досить перебільшив вплив воєнного часу: «До 1914 року слово пропаганда входило тільки в словники з літератури і було наділене гідним значенням. До Світової війни «пропаганда» означала тільки засоби, звертаючись до яких прихильник політичної чи релігійної віри стверджував «незвернених» прийняти іï. Після двох років 3 того часу це слово ввійшло в обіг простих селян і стало випускати отруйні корені. У кінці кінців цим словом стали прикривати відкриту брехню.

Більшість пропагандистського матеріалу Першої світової війни містило в собі перебільшення і брехню. Книги, які відкривали істинну природу та призначення цього матеріалу, зробили так, щоб слово пропаганда отримало іншу «славу». Найбільш значними роботами такого типу були Harold D. Lasswell, Propaganda Techniques in the World War (New York, 1927); Arthur Ponsonby, Falsehood in War-Time (London, 1928); George Sylvester Viereck, Spreading Germs of Hate (New York, 1930); George G. Bruntz, Allied Propaganda and the Collapse of the German Empire in 1918 (Palo Alto, Calif., 1938); Squires, указ. соч.; James R. Mock and Cedric Larson, Words That Won the War (Princeton, N.J., 1939); H.C. Peterson, Propaganda For War (Norman, Okla., 1939); James Morgan Read, Atrocity Propaganda 19141919 (New Haven, Conn., 1941) [3].

Негативне ставлення до пропаганди, характерне для 1920-30x рр., було перш за все результатом асоціації цього слова з діями, які здійснювались у воєнний час, та засуджувались як такі. Більше того, участь у війні розглядалось деякими державами як помилкове. Таке ставлення повною мірою могло бути посилене недовірою протестантів до католицизму, з яким це слово першочергово асоціювалось. Висловлювались також пропозиції, перш за все психоаналітиками, про те, що почуття страху та підозри, пов'язані 3 пропагандою, $\epsilon$ результатом психологічної невпевненості й морального приниження в суспільстві під час соціальних конфліктів (Ernst Kris, "The "Danger" of Propaganda", American Imago, II (1941), 3-42; "Some Problems of War Propaganda", Psychoanalytic Quarterly, XII (1943), 38199 [4]).

Кріс та Лейтес виділяють основні пункти, за якими пропаганда під час Другої світової війни відрізнялась від попередньої, що проводилась у період Першої світової війни, та зводять їх до наступного (Ernst Kris and Nathan leites. 'Trends in Twentieth Century Propaganda', in Psychoanalysis and the Social Sciences, I (1947), 393-409):

Пропаганда носила більш тверезий характер, оскільки використовувалось менше слів із високим оціночним потенціалом. 
Буламеншморалістичною, акцент робивсяна фактичних даних на шкоду висловлювань яких-небудь переваг.

У ній містилось більше значимої інформації [5].

Існує значна кількість дефініцій «пропаганди», більшість з яких зводиться до таких дій: маніпуляція, переконання, примус і таке інше. Один із найбільш відомих дослідників психологічної війни Поль Лайнбарджер, визначив пропаганду: «<...> як організоване переконання без застосування насильницьких заходів» [6, ст.231]. Лайнбарджер уважав, що сучасні війни не можуть проводитись без пропаганди, оскільки вона $\epsilon$ дієвим засобом ненасильницького таємного примушення людини: «пропаганда може стати дійсно зброєю психологічної війни науковою за духом і перетвореною на мистецтво, якщо проведення пропагандистських операцій буде контролюватися на основі наукових методів» [6, с. 249].

У науковій статті В.О. Василишин автор відзначає, що під пропагандою розуміється певна форма комунікації, яка виражається в поширенні фактів, аргументів, чуток та інших відомостей з метою впливу на стан суспільної думки чи громадської позиції та їі формування/ «переформування» в інтересах того, хто здійснює зазначену пропаганду. У широкому розумінні цього слова під нею розуміють поширення соціальних, політичних, природнонаукових та інших знань із метою їх утілення в суспільну свідомість [7].

У свій час Гарт Йовет та Вікторі О’Доннел запропонували коротке визначення терміну «пропаганда»: «пропаганда»- це умисні, систематичні спроби змінити сприйняття, маніпулювати пізнанням та спрямовувати поведінку для досягнення реакцій, яка веде до бажаного наміру пропагандиста» [8. ст.7].

Більш змістовним убачається визначення Р.А. Нельсона: пропаганда нейтрально визначається як систематична форма цілеспрямованого переконання, яке намагається вплинути на емоції, погляди, думки й дії визначеної цільової аудиторії з політичною, ідеологічною чи комерційною метою через контрольовану передачу односторонніх повідомлень (які можуть узгоджуватись з фактами або ні), безпосередньо або через канали мас-медіа. Пропагандистські організації залучають пропагандистів, які займаються пропагандою - безпосереднім, практичним створенням та розповсюдженням таких форм переконання» [7], [9, ст. 232-233].

Визнання поняття «пропаганда» надане майже у всіх енциклопедичних словниках, які досить повно розкривають сутність цього процесу. У цих джерелах також відзначається, що на відміну від об'єктивної подачі інформації, пропаганда подає інформацію, яка направлена насамперед для впливу на аудиторію. Пропаганда часто подає інформацію вибірково (хоча не до кінця сказана правда це теж брехня), щоб спонукати до певних узагальнень, або використовує емоційно заряджені повідомлення, щоб провокувати радше емоційну, ніж раціональну реакцію на подану інформацію. Бажаним результатом $€$ зміна ставлення до суб'єкта в цільовій аудиторії. Щоб просувати таємні політичні плани, пропаганда може використовуватись як форма політичного протистояння [8, ст. 41].

Незалежна правозахисна організація Артикль 19 (ARTICLE 19), що працює в усьому світі з метою захисту та просування права на свободу вираження поглядів, відзначає, що в міжнародному праві немає узгодженого визначення терміну пропаганди, зокрема пропа- ганда війни чи риторика ненависті (мова ворожості). Такі автори як Мак Гунагл, вказуючи на поняття «війни» i «пропаганди» як на два приклади «важко визначених термінів», відзначають, що «пропаганда» $€$ достатньо широким поняттям, яке охоплює «низку різних видів вираження думок, поглядів, що відрізняються за шкідливістю змісту, штучності їх подачі, стратегії розповсюдження та тяжкості наслідків». Інші автори звертають увагу на те, що в Римському статуті Міжнародного кримінального суду відсутній такий склад злочину як пропаганда війни, та наполегливо доводять, що це «пряме та публічне підбурювання до агресії». Тому вони повинні бути включені в Римський статут Міжнародного кримінального суду як самостійний (окремий) міжнародний злочин [11].

Генеральна Асамблея Організація Об'єднаних Націй у резолюції «Заходи, що повинні вживатися проти пропаганди та розпалювачів нової війни» опосередковано тлумачить термін «пропаганда війни», відзначаючи, що вона «засуджує будь-яку форму пропаганди війни, яка ведеться, яка має ціль чи здатна створити чи посилити загрозу миру, ініціювати порушення миру чи акт агресії». Тим самим Організація Об'єднаних Націй визначила, що пропаганда війни спрямована на створення чи посилення загрози миру, порушення миру чи акту агресії і може проявлятись у різних формах [12].

Висновки. Зацікавленість питанням пропаганди непостійна в часі, превалює акцент на воєнній пропаганді, особливо ворожій. Проведений аналіз дає підстави зробити висновки, що воєнний контекст уживання слова пропаганда значно вплинув на значення самого слова, ставлення до пропаганди, а також методи, що застосовуються при їі вивченні.

В міжнародному праві немає узгодженого визначення терміну пропаганди. Поняття «війни» $\mathrm{i}$ «пропаганди» як два приклади «важковизначених термінів» означають таке: «пропаганда» $\epsilon$ достатньо широким поняттям, яке охоплює «низку різних видів вираження думок, поглядів, які відрізняються за шкідливістю змісту, штучності їх подачі, стратегї̈ розповсюдження та тяжкості наслідків. Разом із цим у Римському статуті Міжнародного кримінального суду відсутній такий склад злочину, як пропаганда війни, та наполегливо доводиться, що «пряме та публічне підбурювання до агресії», чи пропаганда війни, повинні бути включені у Римський статут Міжнародного кримінального суду як самостійний (окремий) міжнародний злочин.

Приходимо до висновку, що пропаганда війни - це інструмент спрямованого тиску однієї держави на суспільство, населення, соціальні групи іншої держави, який не завдає прямої руйнації об'єктів матеріального світу, але призводить до деформації суспільної свідомості, загрози суспільній психології, національній єдності. Тобто пропаганда війни має яскраво виражені негативні наслідки для суспільства, непомітні на перший погляд через те, що прояви деформації психічного стану людини проявляються лише згодом.

\section{Література}

1. Прокопенко Д. Ю. Особенности политической пропаганды в современных российских средствах массовой информации : сущность и механизмы влияния : автореф. дис. на соискание науч. степени канд. полит. наук : 23.00.02 / Д.Ю. Прокопенко ; Моск. гос. ин-т междунар. отношен. (Ун-т) МИД РФ. М., 2005. 32 с. 
2. Феллоуз Эрвин В. «Пропаганда»: история слова. URL: file:///propaganda-istoriya-slova\%20(2).pdf.

3. Kearney, M., \& Kearney, M. G. (2007). The prohibition of propaganda for war in international law. Oxford University Press.

4. McGoldrick, D. (1991). The Human Rights Committee: its role in the development of the International Covenant on Civil and Political Rights. Oxford: Clarendon Press.

5. Mendel, T. (2012). Does International Law Provide for Consistent Rules on Hate Speech?. The content and context of hate speech: Rethinking regulation and responses, 417-429.

6. Лайнбарджер П. Психологическая война / П. Лайнбарджер . М. : Воениздат, 1962. 350 с.

7. Василишин В.О. Основні підходи до розуміння пропаганди тероризму. Інформація $i$ право. № 2 (17). 2016. С. 99-105.

8. Garth Jowett and Victoria O'Donnell, Propaganda and Persuasion, 4th ed. Sage Publications, 2005. 448 p.
Протидія злочинності: проблеми практики та науково-методичне забезпечення

9. Richard Alan Nelson, A Chronology and Glossary of Propaganda in the United States. Greenwood Press, 1996. 340 p.

10. Деструктивна пропаганда : шляхи протидії та проблеми відповідальності : матеріали науково-практичної конференції, (М. Київ, 21 травня 2015 р.) ; упорядн. : Фурашев В.М., Поперечнюк В.М. К. : ТОВ «ІВА», 2015. 197 C.

11. McGonagle, T. (2011). Minority rights, freedom of expression and of the media: dynamics and dilemmas. Intersentia, Cambridge - Antwerp - Portland.

12. Резолюції 110 (II) другої сесії Генеральної Асамблеї $\mathrm{OOH}$ «Заходи, що мають вживатися проти пропаганди та розпалювачів нової війни» від 3.11.1947.

Коруч У. З., кандидат юридичних наук, начальник відділу міжнародних зв'язків Тернопільського національного економічного університету 